\title{
Existing Problems and Improving Methods in the Classroom Teaching of Primary and Secondary Schools
}

\author{
QingHua Li ${ }^{1, a}$, Qingpeng Huang ${ }^{2, b}$ and Dong Xue ${ }^{1,3, c^{*}}$ \\ ${ }^{1}$ College of Opto-Electronic Engineering, Zaozhuang University, Zaozhuang 277160, China \\ ${ }^{2}$ College of Music and Dance, Zaozhuang University, Zaozhuang 277160, China \\ ${ }^{3}$ Zaozhuang Engineering Research Center of Terahertz, Zaozhuang 277160, China \\ a1185184733@qq.com, b musichqp@163.com, ${ }^{\mathrm{c}}$ fiberlaser@126.com \\ * The Corresponding Author
}

Keywords: Primary and secondary school; New curriculum reform; Classroom teaching; innovation method

\begin{abstract}
Adhering to education, serving for socialist modernization, serving the people, combining production labor with social practice, and cultivating socialist builders and successors in all aspects of moral, intellectual, physical and aesthetic development." Is our country's education policy but many students today appeared to study hard, even the phenomenon of weariness, indirectly affect the cultivation of future talents in China? The main reason is that the problem of classroom education in educational methods makes students lose interest in learning. Therefore, the position and role of teaching methods in the course of teaching can not be doubted. On the one hand, whether the teaching method is right or not is directly related to the quality of teaching and the efficiency of teaching, and the success of students' learning in the classroom. On the other hand, it is more related to what kind of people to cultivate students. Therefore, in the reform of teaching methods, it is a major issue in the study of modern teaching theory to reflect on its existing problems and explore its innovative strategies.
\end{abstract}

\section{Introduction}

Our education has always been exam oriented education as the main mode. Due to the variety of assignments and the variety of examinations, many students have lost interest in learning, and even have boredom [1]. In addition, some teachers in the classroom are influenced by the one-sided pursuit of intellectual education. In the process of teaching, they are not to guide students to become masters of learning, but to use students as containers of knowledge, blindly instilling, and rarely consider students' acceptance level and interest needs. In fact, the teacher's "teaching" is for the students to "learn". Students' knowledge of things and knowledge is not taught by teachers. Only when they are actively using their brains and actively exploring knowledge, can they achieve all-round development [2]. It can be seen that teaching method, as an important part of the whole structure of education and teaching process, directly determines the success or failure of teaching, the level of efficiency and what kind of people to cultivate students [3].

Nowadays, teachers, as guides, have the following three main problems in teaching methods:

The Goal of Teaching is not Clear and The Focus is not Outstanding. It is not difficult to find that some teachers begin to teach in class when they are in the classroom. They always talk about class. They are all right, blackboard writing is also very comprehensive. There are interactions between teachers and students in the middle. Only a lesson makes students very blind: what should we learn in this section? What should students master? As the teaching goals are not clear, the students will not be able to consolidate and self-test. There are too many teaching goals, too large, the emphasis is not prominent, so that the classroom teaching leisure and lack of condensation. Because the content is too much, the target is dispersed, and it is not in line with the reality of students. In addition, teachers guide too free textbooks, and lose the discipline of teaching materials, so teaching contents cannot be closely linked to goals. Secondly, and some teachers do not pay 
attention to the implementation of emotional goals. In teaching, the best time to achieve emotional goals is to lose this important opportunity. They only pay attention to teaching, do not care about education, and disconnect education and teaching. There are also emotional goals to be pulled out alone, cannot be organically integrated into or imperceptibly knowledge teaching.

The Lack of Innovative Teaching and the Old-Fashioned Methods of Education. Because of the influence of exam oriented education, classroom teaching represses the students' innovative consciousness and innovation ability in many aspects. First of all, we still adhere to the teaching method of instillation and rote learning in terms of value orientation, ignoring students' independent, lively and flexible learning, insisting on classroom instruction, ignoring teaching practice and cultivating students' practical ability. Secondly, it is not reasonable to plan and design courseware. It can' $\mathrm{t}$ accurately grasps students' psychological activities, do not pay attention to students' classroom reactions, but blindly follow the lesson plan. All of this is not conducive to the cultivation of students' innovative spirit and ability, also make the classroom teaching function is not very good to play.

In the information society, many ways of teaching and learning have undergone profound changes, but the path and mechanism of teaching and learning have not changed. The requirements for teachers are higher and stricter, but the duty of teachers to teach and educate people has not changed. A teacher can not only be a teacher who teaches the knowledge of books, but is a "big man" to shape the character, character and taste of the students. It is necessary to combine the education of knowledge with the education of values and ability, and integrate the ideological guidance and values into the teaching of every course [4].

The Subject of Teaching is Neglected and the Object of Education is not Clear. The fundamental purpose of the classroom teaching advocated by the reform of teaching methods is to "make every effort to realize the student's main position" [5]. But the current situation of teachers is still in the classroom teaching is still the protagonist, students must memorize Scripture, students just a nose supporting. The students are always in a passive role in the classroom. It is impossible for students to "make students become the main body of classroom teaching" and become the center of teaching reform. Some teachers still take the book knowledge and self as the standard, the student's learning revolves around the teacher's teaching, and the "bilateral activity" has become a "unilateral activity". It is mainly manifested in the heavy conclusion, the light process, the neglect of the students' thinking process and the diversification of the method of solving problems. The imparting of the knowledge of books, the cultivation of light practice ability, the study of the results, the light of the learning process, the emphasis on the examination results, the neglect of the development of the overall quality, etc. [4]. This is not only detrimental to students' independent thinking and learning, but also hinders them from developing fully and freely, and even interrupts the students' thinking of learning and thinking.

In view of the above three aspects, I briefly explain my personal views on educational methods

To Make Clear the Goal of Teaching and to Cultivate Students' Interest. The classroom teaching is the process in order to achieve the goal and the teaching content in the form of teaching, teachers should pay more attention to the teaching contents in the teaching process, namely knowledge, the teaching form, rather than excessive design teaching form and neglects the teaching content, the form determines the content will be difficult to pursue the quality of teaching, contrary to the original intention of education. The teaching content determines the teaching goal, strives for the students to master the knowledge joyfully, and pays attention to the individual development of the students. Teaching content and teaching aim are the cornerstones of a class. The form of teaching can be changed to change the form of teaching [6]. Therefore, in the lecture, the teacher should emphasize the importance of a knowledge point, emphasize the relation between the knowledge and the difficult problem, put the problem into several related problems according to the degree of difficulty, small slope type progressive layers, draw easy, from easy to difficult. Pay attention to the process and method, study the teaching materials carefully, and solve a prominent problem in each class. Avoid the problem of sea war, and guide the students to find out the idea of solving problems around the typical problems [7], To understand the students' ideas and the degree 
of knowledge, to solve problems pertinent, to be refined and concise. In order to realize the interaction between students and students, interaction between teachers and students, to help students in accordance with their aptitude, Teaching benefits teachers as well as students. In addition, the teacher should let the students learn to listen to the class, to remind the students to pay attention to the example, and to explain what the problem is. Only clear the class of a complete knowledge system framework and teaching objectives, curriculum standards, textbooks and put together, in order to scientifically determine the teaching focus, static difficulty and key, and makes the students' thinking always focus on the lecture, towards the teaching target requirements development.

The process of learning is very boring, and teachers cannot guarantee that all the content can make students have direct interest. At this time, we can cultivate students' indirect interest to achieve the purpose of teaching, such as doing some in class tests, timely evaluating the new situation of students, encouraging students to develop learning competitions, etc., are all common ways to cultivate students' interest in learning. Teachers should be strict with students, cultivate students' willpower to overcome difficulties and increase students' confidence.

Constructing Innovative Classroom Teaching and Creating a Relaxed Classroom Atmosphere. The essential difference between innovative teaching mode and traditional teaching mode in the teaching goal is to instill knowledge, let students memorize, but in the process of teaching more emphasis on cultivating students' thinking ability and innovation ability and operation ability. This requires enough space for teachers in the teaching schedule to show students' personality and talents; secondly in time arrangement, theme selection, research methods and conclusions: determine aspects will have more freedom; again we should pay special attention to education, to play the advantages of each student's personality and potential. Traditional classroom teaching often leaves no room for students to find problems and explore problems, and even intentionally or unintentionally kill students' inspiration and insight. Innovative classroom teaching requires teachers to create certain situations selectively and purposefully, so that students can understand what they should learn, how to learn and what kind of requirements and goals they want to achieve. Teachers should also be good at setting up cognitive conflicts so that students can learn to think independently. The questions formed by the students' independent thinking will stimulate the students' strong interest in learning and the desire for knowledge, and pave the way for the next step of self-study.

With the development of science and technology, the means of teaching are becoming more and more modernized. The development of modern science and technology for the school teaching has provided material basis to new, multimedia teaching technology as an example, this new teaching means the processing ability of the video signal and the ability of TV integrated processing, multimedia computer storage and transmission of voice, text, images, graphics, graphics, animation and other information in the together, the formation of multimedia interactive learning environment, this environment can be illustrated with a combination of static and dynamic, sound and emotion, and the formation of audio-visual integration, expression of holographic, provide a vivid effect for teaching. At the same time, the interactive interface and window type operation of graph, text, sound, image and so on provide great convenience for learning. Some difficult teaching methods, such as virtual reality, distance learning and experimental teaching, can be achieved by modern teaching methods [1]. Compared with the traditional teaching in the language as the main medium for transmitting information, on the blackboard and chalk as the main teaching method, modern teaching method with slides, radio, recording, film and multimedia equipment represented will undoubtedly make students get more intuitive understanding of the knowledge, the students' intelligence fully developed [7], to meet the majority of the students in classroom needs.

Therefore, to speed up the modernization of teaching means, the modern multimedia teaching methods applied to classroom teaching, will enhance the attraction for students to improve teaching effectiveness, but also to enable students to learn new knowledge to keep pace with the environment has always been networked and intelligent, to better stimulate the creativity of students. Teachers should also learn from the psychological point of view, pay attention to students' classroom 
reactions, explain in plain language, explain principles in vivid and interesting examples and activities, and create a relaxed, safe and reliable classroom atmosphere.

Take the Students as the Main Body and Train the Students to Develop in an All-Round Way. Modern psychology believes that the participation of students is a primitive mechanism to promote students' learning. Only by making students become the main body of classroom teaching activities, can students share their due rights and undertake corresponding obligations in teaching activities [8]. This requires teachers to change the traditional and inherent teaching ideas, classroom teaching is not only a process of teaching, but the process of teaching and learning interaction, students are the real subject of learning, but also play a leading role in the classroom, only let students actively participate in the classroom is vivid classroom, it is smart classroom [9] .

Is the common progress of Teaching benefits teachers as well as students. teachers and students in the teaching process, the teacher is no longer the main position, and to extricate from teaching, actively innovate teaching. We should fully believe in students, let them go, teach them how to learn, and let them learn themselves [2]. Should pay full attention to the students' participation in the full and full course, leave the students more time and space activities in the classroom, learning to promote the development of the subject, the function of curriculum is to let students in learning knowledge and skills can also improve and enhance the function of the bird, can let the student have internalized, and the correct emotion, attitude, values and morality in the process of internalization, enables the student to have the awareness, interest, have the responsibility to participate in teaching activities [10] .

On the other hand, teachers should care about all the students, respect students' personality, respect for law and the physical and mental characteristics of the students' age, equal and fair treatment of students, students of Jinan Yanci students, good teachers and helpful friends; protect the safety of the students, care for students' health, protect the rights and interests of students, not irony, in the educational and teaching activities sarcasm, discrimination against students, seriously study the new curriculum standard, "people-oriented" pay more attention to the students, each student ability and the degree of attention, to cultivate the concept of educating people in the first place, the teachers should assume this responsibility, and always put this concept through classroom education [5]. We should also be good at developing students' interest in learning, stimulating students' desire for learning, shaping healthy personality of students, and making them lively, healthy and free.

\section{Conclusion}

As the saying goes " A man of true worth attracts admiration." the teacher as the guide of students, to be dutiful to teach the good book, to do their duty. More importantly, we should care for and care for every student with a love, improve our teaching methods, and strive to cultivate students into fully developed social useful talents.

\section{Acknowledgements}

This work is supported by Shandong provincial art education project (No.YJ201612093); Science and technology program of Zaozhuang (No. 2016GX31); The educational reform projects of Zaozhuang University (No. YJG16028).

\section{References}

[1] T. Zhang : Journal of Modern Education, (2006) No.4, (In Chinese)

[2] X.L. Hao: Research on Teaching Reform, (2012) No.16, (In Chinese)

[3] Z.Z. Liu: Classroom Teaching-The Main Channel of Educating People, (2017) No.10, (In Chinese)

[4] Y. Wang: Education and Scientific Research in Ningxia, (2016) No.2, (In Chinese)

[5] B.K. Wang: Problems and Research Countermeasures in primary and middle school classroom teaching (MS., Hebei University, China 2012), (In Chinese) 
[6] H. Xu, Q.H. Wu: Basic Psychology (Beijing Normal University press, China 2012)

[7] E.B. Yang, D. Yao: Intelligence, (2012) No.23, (In Chinese)

[8] H. Xu, J.L. Fu: Basic Pedagogy （Beijing Normal University press, China 2012)

[9] Y. Ge: Scientific and Technological Information, (2007) No.25 (In Chinese)

[10] L.J. Shi: Research on the implementation degree of the curriculum reform of basic education (Ph.D., Northeast Normal University, China 2016), (In Chinese) 